\title{
Effect of Consumer Ethnocentrism and Perceived Quality of Product on Buying Behavior of Domestic and Foreign Food Products: A Case Study in Pekanbaru, Riau, Indonesia
}

\author{
Nanda Amalia Rahmawati* \\ Department of Family and Consumer Sciences, \\ Faculty of Human Ecology, \\ Bogor Agricultural University
}

\author{
Istiqlaliyah Muflikhati \\ Department of Family and Consumer Sciences, \\ Faculty of Human Ecology, \\ Bogor Agricultural University
}

*Corresponding author: nandaamaliarahmawati@gmail.com

\begin{abstract}
Due to the entry of foreign food products, not only domestic food products does Indonesia provide to the consumers, but also foreign food products. This study aimed to analyze the effects of consumer ethnocentrism and perceived quality product on the buying behavior of domestic and foreign food products. This study used cross-sectional design study involving data from 100 consumers of Bawah Market Pekanbaru who were chosen by convenience sampling technique. The results showed that the respondents had a medium level of consumer ethnocentrism. They perceived the quality of domestic food products higher than that of foreign food products. The results of the multinomial logistic regression test showed that ethnocentrism and perceived quality of domestic food products had a significant negative effect on the food product purchases. Specifically, consumers who had a higher level of ethnocentrism were less likely to purchase foreign food products. Meanwhile, consumers who had a higher level of perceived quality of domestic food product were less likely to purchase the mixture of domestic and foreign food products.
\end{abstract}

Keywords: ethnocentrism, buying behavior, perceived quality of the product

\begin{abstract}
Abstrak. Masuknya produk makanan luar negeri ke Indonesia menyediakan konsumen alternatif bagi produk dalam negeri. Penelitian ini bertujuan untuk menganalisis pengaruh etnosentrisme konsumen dan persepsi kualitas produk terhadap perilaku pembelian produk makanan dalam dan luar negeri. Penelitian ini menggunakan desain cross sectional study dengan data yang diperoleh dari 100 orang konsumen di Pasar Bawah Pekanbaru yang dipilih menggunakan convenience sampling technique. Hasil penelitian menunjukkan etnosentrisme konsumen pada umumnya mencapai tahap sedang. Persepsi kualitas produk makanan dalam negeri lebih tinggi daripada persepsi kualitas produk makanan luar negeri. Hasil uji regresi logistik multinomial menunjukkan bahwa etnosentrisme dan persepsi kualitas produk dalam negeri memengaruhi pembelian produk makanan secara signifikan dan negatif. Konsumen yang memiliki etnosentrisme yang tinggi kurang cenderung untuk membeli produk luar negeri. Demikian juga, konsumen dengan persepsi kualitas produk dalam negeri yang tinggi kurang cenderung untuk membeli produk campuran dalam dan luar negeri.
\end{abstract}

Kata kunci: etnosentrisme, persepsi kualitas produk, perilaku pembelian 


\section{Introduction}

Globalization has resulted in greater market openness (Ministry of State Secretariat of the Republic of Indonesia, 2014) as well as greater openness to other aspects such as information, technology, culture, and marketing. Indonesia's participation in the open trade enables foreign products to enter the market of Indonesia. Indonesian producers should prepare the attack of foreign products entering Indonesia that will possibly shift the position of domestic product sales. Moreover, foreign products will be easily found in both traditional and modern markets in Indonesia.

The product is produced to fulfill the needs and desire of consumers (Sumarwan, 2011). A great number of foreign products that come to Indonesia in the form of products are cloth, food (packaged or processed), and others. These various products make consumers have an alternative choice of products from domestic and foreign products. Food products are available in different types, shapes, and diverse kinds (Sumarwan, 2011). Individuals strive to meet physiological needs, especially eating than any other needs, the need for food can be met with food products (Ruwani, 2013). The segments of consumer's character are also different, varying from the preference for buying products. The tendency of Indonesian consumers is to buy more products from abroad, and it is realized by domestic producers, so the producers of domestic products must rebrand and label their products which sound like foreign products so that the resale value becomes higher (Kompas, 2008).

One of the cities in Indonesia, which sells foreign products is Pekanbaru. Geographically, Pekanbaru is one of the towns in Indonesia located close to the neighboring countries - Malaysia and Singapore. Pekanbaru's government has openly accepted foreign retailers who want to invest in Pekanbaru as long as they follow the rules. The carrying value of the investment increases every year. The data shown from Infoku, 2016 have shown that even until the end of November 2015, this has reached Rp 11.8 trillion. In 2015, Pekanbaru recorded a population of 1.1 million inhabitants (Riau, 2015). The total of population indicates the number of consumers who will buy the product. There are also numerous shopping centers that sell domestic and foreign food products in Pekanbaru. There are many shopping centers that encourage people to visit the shopping centers in order to make the consumers see the products and eventually they are interested in buying the products. (Alfitri, 2007). One of the sale centers in Pekanbaru is Pasar Bawah. This market provides packaged and processed food products both from the domestic and foreign countries. The positioning of domestic and foreign products is not significantly different, all products from foreign and domestic are sold in one place. Therefore, these types of products can be directly accessed by the consumers. The consumers are now offered with a greater variety of domestic as well as foreign products with different qualities and prices to choose from.

According to Khan (2006), as cited in Sumarwan et al. (2013), consumers' purchase behavior could be influenced by external and internal factors. External factors do not affect the decision-making process directly but filtered through individual determinants (Sumarwan et al., 2013). One of the external factors that affects consumers on purchasing is product quality. Quality has two dimensions that are objective and subjective. Objective quality refers to the physical characteristics that are built into the product while the subjective quality is the quality perception by the consumers (Grunert, 2005). The assessment of the product quality is subjective depends on the respective opinion of consumers which is called as perception (Schiffman and Kanuk, 1983). 
Perception is the process used by the individual to select, organize, and interpret input information to create a picture of the world that has meaning (Sumarwan et al., 2013). Perception is more important than reality because it will affect the actual behavior toward the product (Kotler and Keller, 2007). Consumers will not consider other attributes as long as these products have a good quality so that the perception of product quality beats the assessment of other attributes in deciding the purchase (Sumarwan et al., 2013). Quality perception will influence the consumer's decision to purchase or to use a certain product because it can meet the expectations (Sumarwan et al., 2013). The good perception of product quality will encourage customers to buy the product, and perceived quality of product has a correlation with the intention to buy a product (Purwanto, 2014). The study of Koutroulou and Tsourgiannis (2011) proved that the product quality affected the purchase of domestic food products.

Another internal factor that affects buying behavior is ethnocentrism (Shimp and Sharma, 1987). Ethnocentrism is a belief that it is wrong to buy imported products because it could harm the local economy and also society itself (Shimp and Sharma, 1987). Consumer ethnocentrism is proven when consumers choose to buy domestic over foreign products despite the later superior attributes. The higher of the ethnocentrism, the more consumers will prefer domestic products than foreign products. Still, there are consumers with medium ethnocentrism who will have certain tendency to buy foreign products (Alsughayir, 2013). The study of Part and Vida (2013) proved that there was an effect of consumer ethnocentrism on domestic product quality. Sukmaningtyas and Hartayo (2013) also found that ethnocentrism influenced the buying behavior in food products, particularly fruit.

The previous study that has been conducted concerned only on the consumers' decision stage and only to examine either domestic product or foreign product only. This study examined the actual buying and involved both domestic and foreign products. Generally, the purpose of this study was to analyze the effect of consumer ethnocentrism and quality perception of the product on buying behavior of domestic and foreign food products. Meanwhile, the specific objectives of this research were: 1) to determine the characteristics of the consumer; 2) analyze the ethnocentrism of consumer; 3) to analyze the perceived quality of domestic and foreign food products; and 4) to analyze the effect of ethnocentrism and perceived quality of the product on buying behavior of domestic and foreign food products.

\section{Method}

\section{Participants}

This case study was conducted in Pekanbaru City, Riau. The study was conducted in February and March 2015. The population of this study was consumers who lived in the city of Pekanbaru, Riau. The number of respondents in this study was 100 consumers, who were chosen through non-probability convenient sampling technique using a questionnaire. The criteria to select the respondents were: 1) age 19-50 years; 2) purchase food products in the Bawah Market of Pekanbaru; and 3) be willing to be interviewed. 


\section{Measures}

Data used in this study were primary data consisting of individual characteristics, consumer ethnocentrism, perceived quality of food product, and buying behavior of both domestic and foreign food products. The instrument of ethnocentrism was CETSCALE which was modified from Shimp and Sharma (1987) and Purwanto (2014). CETSCALE consisted of 6 statements rated on a 5-point Likert scale $(1=$ strongly disagree, through $5=$ strongly agree) with Cronbach's alpha $(\alpha)$ of 0.819 . The minimum score and the maximum score were 6 and 30 respectively. The variables in this study were categorized into three classes: low, medium, and high using composite interval class (Puspitawati and Herawati, 2013) based on the total score of the variable with the following criteria: high $(>22)$, medium $(15-22)$, and low $(<15)$.

The instrument of perceived quality of the product that was adopted from Purwanto (2014) consisted of 3 statements on the perceived quality of domestic food products and 3 statements on the perceived quality of foreign food product. The statements were scored on a similar 5-point Likert scale as CETSCALE. Our results reported Cronbach's alphas $(\alpha)$ of 0.763 for the perceived quality of domestic food products and 0.833 for the perceived quality of foreign food products. The minimum and the maximum scores were 3 and 15 respectively. In this study, scores of variables were also categorized into three classes: high $(>11)$, medium $(8-11)$, and low $(<8)$ using composite interval class (Puspitawati and Herawati, 2013).

The instrument of buying behavior was modified from Lestari (2014) with a self-report technique with open and closed questions (mixture) covering the type, quantity, price, and reason to buy a product. The buying behavior of products was seen on the type of product purchased, that is, domestic products purchase, foreign product purchase, or mixture purchase (domestic and foreign purchases). The value of Cronbach's alphas $(\alpha)$ of this instrument was 0.634 .

\section{Analysis}

Analysis of the data used were:

1. Descriptive test was used to describe the consumer characteristics (age, sex, marital status, the length of education, ethnicity, religion, occupation, income, number of family members, consumer ethnocentrism, perceived quality of the domestic and foreign products, and buying behavior).

2. Multinomial logistic regression test was used to analyze the effect on consumer buying behavior. Formula of multinomial logistic regression logit equation is as follows:

$$
g(D x)=\beta_{1} X_{1}+\beta_{2} X_{2}+\beta_{3} X_{3}+\beta_{4} X_{4}
$$

Description:

$g(D x)=$ dummy purchase of food products $(1=$ domestic purchase, $2=$ foreign purchase, $3=$ mixture purchases)

$\beta=$ coefficient

$\mathrm{X}_{1}=$ the length of education (year)

$\mathrm{X}_{2} \quad=$ consumer ethnocentrism (score)

$\mathrm{X}_{3} \quad$ = perceived quality of the domestic food products (score)

$\mathrm{X}_{4} \quad=$ perceived quality of the foreign food products (score) 


\section{Result}

\section{Consumer Characteristics}

The results showed that of 100 consumers surveyed, there was 74 percent of women and 26 percent of men. Most consumer age was 36-50 years old (43\%) and 2535 years old $(21 \%)$ while the average age was 33 years old. Most consumers were Muslim (98\%) and the others $(1 \%)$ were Catholic and Buddhist. The ethnics of consumers were classified into two groups that are Malays and non-Malay. A total of 39 percent of consumer was Malays ethnic and 61 percent of consumer was non-Malays ethnics including Minang, Javanese, Mandailings, Batak, and Sundanese. The marriage status of the consumer was also classified into two, that is, married and unmarried. A total of 61 percent of consumers was not married, and only 39 percent of them was married.

Table 1 Rated minimum, maximum, and mean score of consumer characteristics

\begin{tabular}{lccc}
\hline Variables & Min. & Max. & Mean \pm SD \\
\hline Age (years) & 20 & 50 & $33.03 \pm 10.21$ \\
Number of family members & 4 & 7 & $4.23 \pm 1.29$ \\
(person) & & & \\
Revenue (IDR) & 350.000 & 40 million & 4.134 million \pm 4.984 .622 .21 \\
Length of education (years) & 11 & 18 & $14.85 \pm 1.74$ \\
\hline
\end{tabular}

All of the man consumers were employed, whereas the female consumers were dominated by housewives (39.2\%). City Minimum Wages (CMW) Pekanbaru in 2014 was Rp1.775.000 per month. About 32 percent of consumers had a salary below CMW while as many as 68 percents was above CMW. The number of family members of consumers mostly was about 4 persons (38 percent). There were no uneducated consumers indicated by 9 years of education at minimum. More than half of the consumers in this study both men and women enrolled school for more than 12 years, equivalent to college level.

\section{Consumer Ethnocentrism}

As many as 88 percent of the consumers in this study showed agreement on ethnocentrism and that Indonesian consumer should always buy products that were manufactured in their home country. Nearly 77 percent of the consumers also responded that domestic products turned out to be their option to buy. More than half of the consumers (54\%) also approved that Indonesian people should not buy foreign products because it will turn off the business of Indonesian people itself. Consumers agreed to the purchase of foreign products if the product cannot be obtained in their own country (79\%). However, about 61 percent of consumer did not agree that buying foreign food products was responsible for local people lost their business, and 67 percent of consumers did not agree that buying foreign food products caused the local people lose their jobs. A total of 56 percent of consumers was categorized the medium level of ethnocentrism while 43 percent of consumers was categorized high. The minimum and maximum scores of consumer ethnocentrism value were 11 and 30 respectively. The mean score of consumer ethnocentrism was 19. This indicated that in general they were in the medium level of ethnocentrism. It showed that generally consumer less agreed with all statements of consumer ethnocentrism. 
Table 2 Distribution of the consumers based on consumer ethnocentrism

\begin{tabular}{lcc}
\hline Ethnocentrism & $\mathrm{n}$ & $\%$ \\
\hline Low $(<15)$ & 4 & 4.00 \\
Medium $(15-22)$ & 56 & 56.00 \\
High $(>22)$ & 43 & 43.00 \\
\hline Total & 100 & 100.00 \\
\hline
\end{tabular}

\section{Perceived Quality of Food Products}

Perceived quality of food product was classified into two; the perceived quality of domestic food products and perceived quality of foreign food products. As many as 84 percent of the consumers agreed that quality of domestic food product was good, 82 percent said it was trusted, and well produced perceived by 95 percent of the consumers. That result was similar to the perception of foreign food products. More than half of the consumers agreed that the quality of foreign food products was good and foreigners had the ability to produce high-quality products. On the other hand, about 52 percent of the consumers disagreed that quality of the foreign product was trusted.

Table 3 Distribution of the consumers based on perceived quality of domestic and foreign food products

\begin{tabular}{lcccc}
\hline \multirow{2}{*}{ Category } & \multicolumn{2}{c}{ Domestic } & \multicolumn{3}{c}{ Foreign } \\
\cline { 2 - 5 } & $\mathrm{n}$ & $\%$ & $\mathrm{n}$ & $\%$ \\
\hline Low $(<8)$ & 2 & 2.00 & 7 & 7.00 \\
Medium $(8-11)$ & 22 & 22.00 & 54 & 54.00 \\
High $(>11)$ & 76 & 76.00 & 39 & 39.00 \\
\hline Total & 100 & 100.00 & 100 & 100.00 \\
\hline
\end{tabular}

The minimum and maximum scores of perceived quality domestic food products were 6 and 15 respectively, with the average of the total score were 11.93. This score was categorized into high level. It means that the consumers agreed with all statements of perceived quality of domestic food products. The minimum and maximum scores of perceived quality of foreign food products were 3 and 15 respectively, with the average of the total score were 10.43 categorized in medium level. The analysis resulted that perceived quality of domestic food products was high $(76 \%)$ while the foreign food products were only 39 percent. It indicated that the consumers considered the perceived quality of domestic food products was better than foreign products.

\section{Consumer Buying Behavior}

Consumer purchases were divided into three categories, namely the purchase of domestic products, the purchase of foreign products, and mixture purchases (the purchase of domestic and foreign products). Table 4 shows that most consumers bought only domestic food products $(43 \%)$. The type of domestic and foreign food products purchased by consumers was classified into nine categories. They were chips, nuts, chocolates and candies, biscuit, cakes, beverages, dodol, food stuff, and others which were customized to the products sold in the Bawah Market. 
Table 4 Distribution of the consumers based on the purchases of food products

\begin{tabular}{lcc}
\hline The purchases of food products & $\mathrm{n}$ & $\%$ \\
\hline Domestic products & 43 & 43.00 \\
Foreign product & 15 & 15.00 \\
Mixture purchase (domestic and foreign products) & 42 & 42.00 \\
\hline Total & 100 & 100.00 \\
\hline
\end{tabular}

Based on consumer purchases, the type of domestic food products mostly purchased were crackers and chips while of foreign food products were chocolates and candies. The result showed that the reason for purchasing all types of domestic and foreign food product was because of the taste. Meanwhile, packaging was the second reason for the consumer to purchase certain food products. The volume of the products was not the important reason for the consumers. Most consumers of Bawah Market chose domestic and food product for souvenirs. The results showed that the average expense of purchasing foreign food products was higher than that of purchasing domestic food products. It indicates that the consumer needed much more money to buy foreign food products than to buy domestic food products.

\section{Factors That Affect Purchase of Domestic and Foreign Food Products}

The analysis used to examine the factors affecting on domestic and foreign food products was the multinomial logistic regression test. This analysis was used because the independent variable $(\mathrm{Y})$ of this study were nominal data type (purchase of the product which is represented as a dummy variable). Meanwhile, the dependent variables (X) examined were income, ethnocentrism, perceived quality of domestic food products, and perceived quality of foreign food products which were selected based on relation analysis test and from literature for more significant results.

Multinomial logistic regression test was used for further determination of the influence differences between the food product purchase behavior of consumers that had more than two categories (i.e. domestic food products purchase only, foreign food products purchase only, and mixture purchase) with a nominal scale of the independent variable (Hosmer and Lemeshow, 2000). Furthermore, food buying behavior of consumers was categorized into three; consumers who buy domestic food products just as a comparison, consumers who buy foreign food products, and consumers who buy mixture food products (domestic and foreign food products).

The results of the simultaneous analysis showed that the results can be accepted based on the analysis results of the goodness of fit represented by the R-square of 0.151 . It described the proportion of the variables that affected buying behavior of food products in this model about 15.1 percent and the rest $(84.9 \%)$ were the variables that were not observed in this test model. The level of the true model less than 0.1 or 90 percent with the p-value of 0.080 with the chi-square value of 14.065 . 
Table 5 The results of multinomial logistic regression test

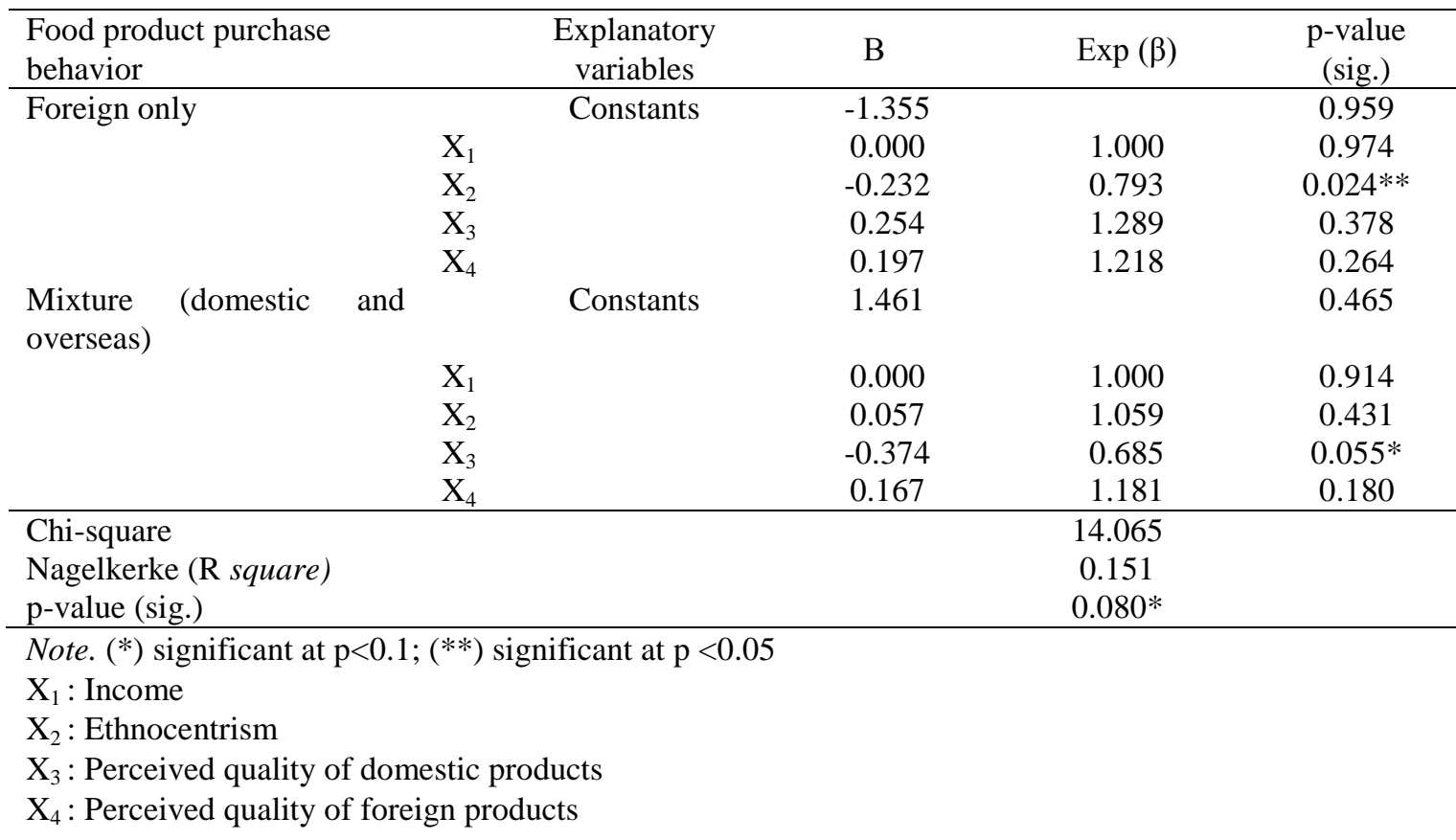

Table 5 shows the odds ratio values in logit 1 (foreign only) and logit 2 (mixture). From the results on variables logit 1, the higher value of ethnocentrism, the lower opportunity of the consumers that have to buy foreign food products only (about 0.793 times). It was lower than the purchase of domestic products only. Based on this result, ethnocentrism $(B=-0.232 ; p=0.024)$ gave a negative effect on the purchase of foreign food products. The results also showed that the income and perceived quality of food product gave a positive effect on the purchase of foreign products, but it was not significant. It means that the hypothesis that income and perceived quality of food product effected the purchase of foreign food products was not applicable in this study.

From the value of odds ratio for logit 2 (mixture), it showed that the higher perceived quality of domestic food products, the lower opportunity of consumers had to buy both domestic and foreign food products (about 0.685 times). It was lower than the purchase of domestic products only. This showed that the perceived quality of domestic food products $(\mathrm{B}=-0.374 ; \mathrm{p}=0.055)$ gave a negative effect on the purchase of the mixture (domestic and foreign food products). The results also showed that the income and perceived quality of foreign food products gave a positive effect on the purchase of mixture products, but it was not significant. It means that the hypothesis that income and perceived quality of foreign food product effected mixture purchases was also not supported by this study.

\section{Discussion}

Consumer ethnocentrism is considered as a tool that can identify consumers' purchase of domestic and foreign products (Guneren and Ozturen, 2008). The analysis showed that the level of consumer ethnocentrism in this study was categorized in the middle level. This result is in line with the study of Anggasari, Yuliati, and Retnaningsih (2013) showing that consumers also had middle levels of ethnocentrism. 
The results demonstrated that the perceived quality of domestic food products was high while the perceived quality of foreign products was in the middle level. This is in contrast to the study of Purwanto (2014) which stated that the perceived quality of domestic products was low. Most consumers perceived that the quality of food products in Bawah Market was good, trustworthy, and well produced as well as foreign food products. This is the contrast to the study of Vazifehdust and Reihani (2013) that the quality of foreign products was more optimal than of domestic products. The perception of each person to an object will vary, so the perception has subjective nature (Setiadi, 2010). The result difference occurs because of the differences in the characteristics of the consumers involved in the study by age, education, and region of the consumers.

The rate of domestic product purchase was more than of the foreign product purchase. This is consistent with the study of Kalicharan (2014) which described consumers preference on local products compared to foreign products. Price is the amount of money that must be paid to get the usability of the product. Many economists concluded that low prices would result in only a few products on sale than a high price, but the price is sometimes present on the signal quality (Hawkins, Best, and Coney 2001). The purchasing reason of products that have the largest selection was because of the taste of both domestic and foreign products. Koutroulou and Tsourgiannis's study (2011) mentioned the taste was a factor of consumers to buy food products. The purpose of the consumers in buying food products was mostly for souvenirs. Consumers bought products to get the functions, condition, and the meaning of these products. Food depicting the symbol of kinship (Engel, Blackwell, and Miniard, 1995).

Vazifehdust and Reihani (2013) described that the consumers considered high price as a result of the high quality and on top of that, they believed it would enhance their prestige. Consumers are willing to pay the price of products sold (Brosekhan, Velayutham, and Phil, 2013). In line with the explanation of Schiffman and Kanuk (1983), the researchers found that significantly higher-priced product was perceived to have better quality than lower-priced products and consumers had the higher desire to buy the famous product than not famous ones.

The findings based on statistical analysis found that ethnocentrism and perceived quality of domestic food products likely affected the purchase of food products by the consumers. Consumer ethnocentrism had an effect on the selection of the domestic and foreign products (Lajevardi et al., 2014). The results are consistent with the study of Sukmaningtyas and Hartayo (2013) which mentioned that the effect of ethnocentrism was against the purchase of fruit products. High ethnocentrism makes it possible to the high purchase of domestic products (Guneren and Ozturen, 2008). This result is also in line with the study of Shaheen (2004) which stated that quality perception had a significant impact on the purchase. Koutroulou and Tsourgiannis' study (2011) also found that there were quality factors that affected the purchase of local products.

The R-square value in this study was only about 0.151 indicating that the variables in this study predicted the buying behavior of Bawah Market's consumers as big as 15.1 percent while the rest $(84.9 \%)$ was predicted by the variables that were not studied. Based on Sumarwan et al. (2013), when carrying out a purchase, the consumer was influenced by the attitude of other people and unanticipated situations factors and it could change the purchase intention. These factors can be studied further in order to raise $\mathrm{R}$ square in the study of buying behavior on food products.

This study did not use the standard measurement instruments of quality perception of the product and buying behavior. Variable ethnocentrism was not 
discussed in depth on the types of consumer ethnocentrism. Buying behavior of the consumers was measured at the time when the research was done and was not given the standard frequency of purchase. Therefore, future studies may provide the standard frequency of purchases. The method of sampling in this study was convenience sampling method so that these results can not be generalized to the overall consumer and only applied to the example studied alone. Products compared in this study were the domestic and foreign food products so further studies can differentiate similar products, either domestic or foreign products or focus on only one product.

\section{Conclusion and Recommendation}

\section{Conclusion}

Most consumers in this study were female, in the category of middle-aged, did not work or a housewife, and have already married. Based on City Minimum Wages (CMW) of Pekanbaru in 2014, the wages of most consumers were above standard CMW and the length of consumers' education was more than 12 years. The number of family members of consumers was 4 people on average.

The result showed that most consumers were in the medium category of ethnocentrism. The perceived quality of food products must be good, trusted, and well produced so that the consumers have the willingness to buy food products. The consumers in this study perceived the quality of domestic products in the high category while the perceived quality of foreign products was in the medium category.

Most consumers only bought domestic products, while the group of consumers who did mixture purchase of food products (domestic and foreign) was in the second rank, and the consumers who only bought foreign products was in the last rank. The purchase of domestic products was higher than that of foreign products. The average expense of foreign products was higher than that of domestic products and mixtures. The reason that most preferred by consumers was the taste, the purpose of purchasing food products for souvenirs in the first rank and for own consumption in the second rank.

Multinomial logistic regression analysis showed that ethnocentrism and quality perception of domestic products can potentially affect the purchase of food products by the consumers. Ethnocentrism had a negative effect on the purchase of foreign products, as well as the perceived quality of domestic products had the negative effect on the purchase of domestic and foreign products. There were limitations of this study; one of them was convenience sampling method so that the data cannot be generalized to the consumers extensively. Other variables that can be investigated in the further studies are attitude and unanticipated situations.

\section{Recommendation}

1. Results showed that consumer ethnocentrism in this study was in the medium category while the education of the consumers surveyed was 12 years on average. To improve the ethnocentrism of consumers on preferring domestic products, giving education for the consumers to love and choose domestic products should be done intensively. 
2. The R-square value in this study was only 0.151 . This happened because the variables studied were limited. Further study should be conducted by adding other variables that have not been investigated such as the situational and attitudes factors that might affect $\mathrm{R}$ square larger with significant results.

\section{Reference}

Alfitri. (2007). Budaya konsumerisme masyarakat perkotaan (Consumerism culture of urban society). Majalah Empirika, 11(1), 1-9. Retrieved from http://eprints.unsri.ac.id/731/2/Budaya_Konsumerisme_Masyarakat_Perkotaan.pdf.

Alsughayir, A. (2013). Consumer ethnocentrism: A literature review. International Journal of Business and Management Invention, 2(5), 50-54. Retrieved from http://www.ijbmi.org/papers/Vol\%282\%295/version-2/H255054.pdf.

Anggasari, P., Yuliati, L. N., \& Retnaningsih. (2013). Pengaruh etnosentrisme terhadap sikap, preferensi dan perilaku pembelian buah lokal dan impor (Influence of ethnocentrism on attitude, preference, and buying behavior of local and import fruits). Jurnal Manajemen \& Agribisnis, 10(2), 128-136. Retrieved from http://journal.ipb.ac.id/index.php/jmagr/article/view/8485.

Brosekhan, A. A., Velayutham, C. M., \& Phil, M. (2010). Consumer buying behaviour - a literature review. Journal of Business and Management, 10(2), 8-16. Retrieved from http://iosrjournals.org/iosr-jbm/papers/ncibppte-volume-1/1014.pdf.

Engel, J. F., Blackwell, R. D., \& Miniard, P. W. (1995). Consumer Behavior (8th ed.). Chicago, IL: Dryden Press.

Grunert, K. G. (2005). Food wuality and safety: consumer perception and demand. European Review of Agricultural Economics, 32(3), 369-391. doi: 10.1093/eurrag/jbi011.

Guneren, E., \& Ozturen, A. (2008). Influence of ethnocentric tendency of consumers on their purchase intentions in North Cyprus. Journal of Euromarketing, 17(3/4), 219231.

Hawkins, D., Best R. J., \& Coney, K. A. (2001). Consumer Behavior: Building Marketing Strategy (8th ed.). New Jersey, NJ: McGraw-Hill.

Infopku. (2016, January 21). Pekanbaru, MEA, dan produk lokal (Pekanbaru, AEC, and local product). Retrieved from http://infopku.com/pekanbaru-mea-dan-produklokal/.

Kalicharan, H. D. (2014). The effect and influence of country-of-origin on consumers perception of product quality and purchasing intentions. International Business \& Economics Research Journal, 13(5). doi: 10.19030/iber.v13i5.8760.

Kompas. (2008, December 22). Tidak "pede" dengan merek "made in Indonesia" (Not confident with "made in Indonesia" brand). Retrieved from http://nasional.kompas.com/read/2008/12/22/20040276/Tidak.Pede.dengan.Merek. Made.in.Indonesia.

Kotler, P., \& Keller, K. L. (2007). Manajemen Pemasaran (12th ed.). (Molan, B., Tran.). Jakarta, Indonesia: PT Indeks.

Koutroulou, A., \& Tsourgiannis, L. (2011). Factors affecting consumers' purchasing behaviour towards local foods in Greece: the case of the prefecture of Xanthi. Scientific Bulletin - Economic Sciences, 10(16), 1-14. Retrieved from http://economic.upit.ro/repec/pdf/2011_2_4.pdf. 
Lajevardi, M., Mameshi, E. G., Fakharmanesh, S., Shirzadegan, \& Milad, L. (2014). Investigating the effect of customer ethnocentrism on awareness of customer from product origin. Advances in Environmental Biology, 8(9), 267-277. Retrieved from http://www.aensiweb.com/old/aeb/special\%204\%202014/267-277.pdf.

Lestari, T. R. (2014). Pengaruh etnosentrisme, sikap, dan preferensi terhadap perilaku pembelian buah lokal di perkotaan dan perdesaan Bogor [The influence of ethnocentrism, attitude, and preference toward the purchasing behavior of local fruits in urban and rural Bogor] (Undergraduate thesis). Retrieved from http://repository.ipb.ac.id/handle/123456789/69947.

Mangnale, V. S., Potruli, R. M., \& Degufu, H. (2011). A study on ethnocentric tendencies of Ethiopian consumers. Asian Journal of Business Management, 3(4), 241-250. Retrieved from http://maxwellsci.com/print/ajbm/v3-241-250.pdf.

Ministry of State Secretariat of the Republic of Indonesia. (2014). Peluang dan tantangan Indonesia pada Asean Economic Community 2015 [Indonesia's opportunity and challenge in Asean Economic Community 2015]. Retrieved from http://www.setneg.go.id/index.php?lang=en\&option=com_content\&task=view\&id= 7911.

National Population and Family Planning Board. (1998). Kamus Istilah Kependudukan Keluarga Berencana Keluarga Sejahtera. Kantor Menteri Negara Kependudukan [Dictionary of Terms for Population Family Planning Family Welfare]. Jakarta, Indonesia: Author.

Part, O,. \& Vida, I. (2013). The effects of cosmopolitanism on consumer ethnocentrism, product quality, purchase intentions and foreign product purchase behavior. American International Journal of Contemporary Research, 3(11), 144-155.

Purwanto, E. (2014). The effect of consumer ethnocentrism on perceived domestic product quality and purchase intentions among young consumers in Jakarta, Indonesia. International Journal of Asian Social Science, 4(9), 1003-1012. Retrieved from h http://www.aessweb.com/pdf-files/ijass-2014-4(9)-1003-1012.pdf.

Puspitawati, H., \& Herawati, T. (2013). Metode Penelitian Keluarga [Family Research Method]. Bogor, Indonesia: IPB Press.

Putri, A. (2010). Tingkat kepuasan konsumen terhadap produk makanan khas Riau (Kasus di Kota Pekanbaru, Provinsi Riau) [The level of consumer satisfaction on Riau typical food products (Case in Pekanbaru City, Riau Province)] (Unpublished undergraduate thesis). Universitas Riau, Pekanbaru.

Riau. (2015, April 15). Pertumbuhan penduduk Pekanbaru 7 persen setahun [Pekanbaru population growth of 7 percent a year]. Retrieved from https://www.riau.go.id/home/content/2015/04/15/3321-pertumbuhan-pendudukpekanbaru-7-persen-setahun.

Ruwani, A. (2013). Nilai dan tipe konsumen rumah tangga kaitannya dengan perilaku pembelian produk makanan kemasan di wilayah perkotaan dan perdesaan Bogor [Value and type of household consumer buying behavior in relation to packaged food products in urban and rural Bogor]. Jurnal Ilmu Keluarga dan Konsumen, 7(1), 48-57. Retrieved from http://journal.ipb.ac.id/index.php/jikk/article/view/9996/7816.

Setiadi, N. J. (2010). Perilaku Konsumen: Perspektif Kontemporer Pada Motif, Tujuan, dan Keinginan Konsumen [Consumer Behavior: Contemporary Perspectives on Motives, Purposes, and Consumer Desires]. Jakarta, Indonesia: Kencana. 
Schiffman, L. G., \& Kanuk, L. L. (1983). Consumer Behavior (2nd ed.). New Jersey, NJ: Prentice-Hall.

Shaheen, N. (2004). Purchasing behavior: Ethnocentric or polycentric. Journal of Managerial Sciences, 2(2), 221-237. Retrieved from http://www.qurtuba.edu.pk/jms/default_files/JMS/2_2/04_nasir_shaheen.pdf.

Shimp, T. A., \& Sharma, S. (1987). Consumer ethnocentrism: construction and validation of the CETSCALE. Journal of Marketing Research, 24, 280-289.

Sukmaningtyas, A., \& Hartoyo. (2013). Pengaruh nilai dan gaya hidup terhadap preferensi dan perilaku pembelian buah-buahan impor [Influence of value and life style on preference and buying behavior of import fruits]. Jurnal Ilmu Keluarga dan Konsumen, 6(1), 39-48. Retrieved from http://journal.ipb.ac.id/index.php/jikk/article/view/7701.

Sumarwan, U. (2011). Perilaku Konsumen [Consumer Behavior]. Bogor, Indonesia: Ghalia Indonesia.

Sumarwan, U., Puspitawati, H., Hariadi, A., Ali, M. M., Gazali, M., Hartono, S., \& Tara, F. (2013). Riset Pemasaran dan Konsumen [Research of Marketing and Consumer] (3rd ed.). Bogor, Indonesia: IPB Press.

Vazifehdust, H., \& Reihani, N. (2013). Why is young consumers' purchase intention toward foreign luxury good? Presenting framework for young consumer purchase behavior case study: mobile consumers in Iran. Journal of Basic and Applied Scientific Research, 3(5), 914-923. Retrieved from http://www.textroad.com/pdf/JBASR/J.\%20Basic.\%20Appl.\%20Sci.\%20Res.,\%203 $\% 285 \% 29914-923, \% 202013 . p d f$. 